\title{
Systematic 1:500 000 mapping and regional geological studies in central and western North Greenland
}

\author{
Niels Henriksen
}

The first season of the two-year field mapping programme in central and western North Greenland was carried out from June to August 1984. The investigations are a continuation of the 1978-1980 mapping programme in the Peary Land region, adjoining the present area to the east. One of the main aims of the regional geological studies in the present programme is the production of a 1:500 000 map sheet of the area between $J$. P. Koch Fjord $\left(c .40^{\circ} \mathrm{W}\right)$ in the east and north-easternmost Washington Land $\left(65^{\circ} \mathrm{W}\right)$ in the west; the southern boundary of the map sheet is latitude $81^{\circ} \mathrm{N}$, although the Inland Ice in most of the region forms the southern margin of the rock outcrop. A special source rock project (Christiansen \& Rolle, this report), financed by the Danish Ministry of Energy, was fully integrated with the mapping programme.

Logistic preparations for the 1984 work were begun in 1980, with storage of equipment used during the 1978-1980 expeditions to Peary Land, and continued in the summer of 1983 when fuel, equipment and provisions were flown into the Canadian Forces Station (CFS) Alert in north-east Ellesmere Island, Canada (Dawes, 1984). Prior to the 1984 field season topographic and photogeological maps were prepared photogrammetrically for the entire region using a Kern PG-2 stereoplotter instrument with a semi-automatic drawing table supported by a computer system (Dueholm, 1979). The photogrammetric work was based on new wide-angle aerial photographs taken in 1978 at a scale of 1:150 000 and on control points established by the Geodetic Institute, Copenhagen. In all 20 base maps at a scale of 1:100 000 have been constructed.

\section{Logistics}

A tent base camp was established in south-eastern Warming Land (fig. 3) at a site previously used in 1979 by the Geodetic Institute during their ground surveying programme. Two chartered Jet Ranger helicopters and a Twin Otter aircraft were based here, and provided transport, camp moves and helicopter reconnaissance for the geological field teams at intervals of 4-6 days throughout the season. The operation area extended about $500 \mathrm{~km}$ from east to west, and $150-200 \mathrm{~km}$ from south to north. In all about 130 camp sites were established by the 12 geological teams.

The GGU group numbered 37, comprising 12 two-man geological teams and 13 supporting personnel, including seven aircraft crew members. Mobilisation and demobilisation was carried out with the help of the Royal Danish Air Force who airlifted material and personnel to CFS Alert. Here the expedition was given facilities for transit of equipment and personnel, and during the summer the Twin Otter maintained frequent connections between CFS Alert and the base camp in Warming Land. All fuel had been flown in during the summer of 1983 and was stored in the main tank system at Alert, from where it was drawn regularly throughout the season. In late July 1984 a fuel lift with the RDAF C-130 from Thule Air Base brought in the 1985 supplies of Jet fuel to Alert where it is now stored in the main tank 

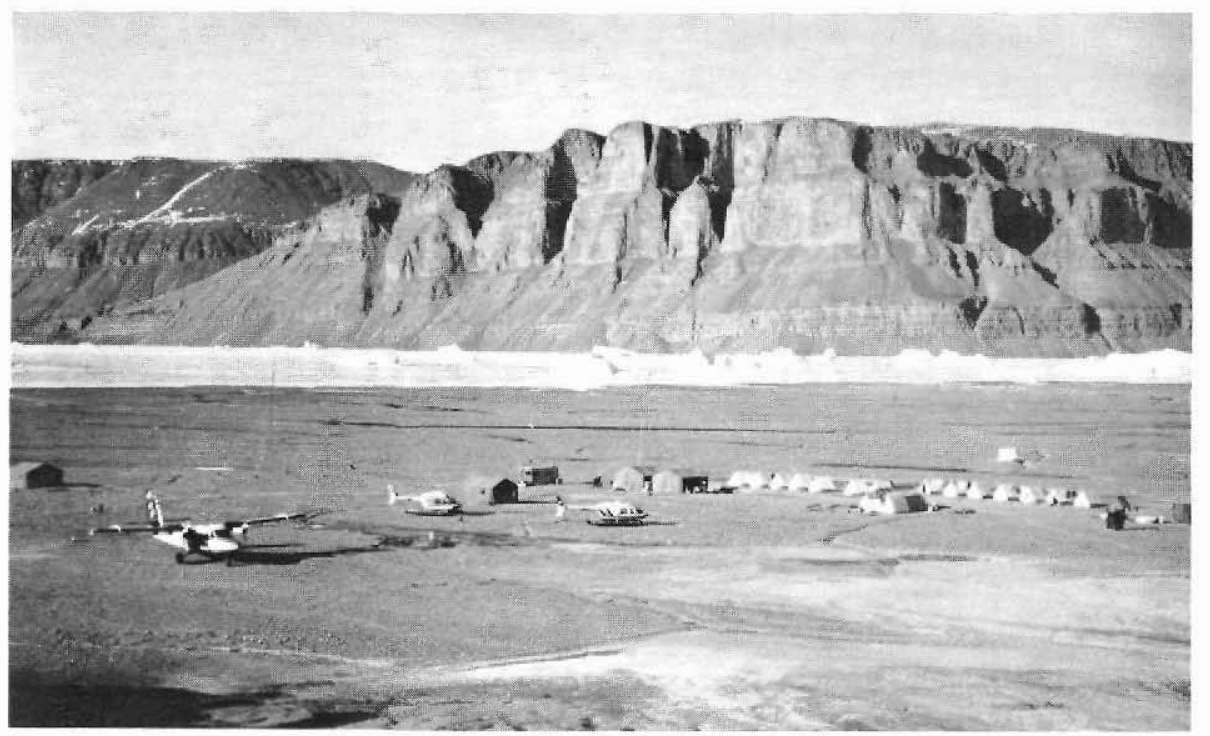

Fig. 3. Tent base camp in Warming Land.

system. At the end of the 1984 season, provisions and some equipment for 1985 were flown from Denmark to Alert where they are stored for the winter. The base camp was largely dismantled after the 1984 season, and all equipment was stored in two huts ready for 1985 use.

\section{Geological investigations}

The 12 two-man geological teams each worked with specific topics or areas of responsibility. Most teams used this first season to obtain an overall view of their working areas; many teams, however, had participated in one or more of the previous seasons' field work in Peary Land, and were thus well acquainted with the geological problems. Previous reconnaissance investigations in the region by GGU afforded a good starting point for the more systematic work. The general geological background was thus well known before the work began, and the planning, distribution of working tasks and commitments of each field party were thus established before the season. This has contributed greatly to the efficiency of the field work, enabling each group to obtain maximum geological benefit from the short field season.

Preliminary results from the expedition will be published in a future publication (Report on the 1984 geological expedition to central and western North Greenland, Rapp. Grønlands geol. Unders.). The present article is based on an internal GGU report ('Express Report, central North Greenland 1984'), to which all the participating geologists contributed immediately after the end of the field season. 
The participating geologists and their main working objects and mapping responsibilities were:

( 1) J. S. Peel \& S. C. Wright:

( 2) M. Sønderholm:

( 3) M. P. Smith \& I. D. Bryant:

( 4) J. C. Escher \& P.-H. Larsen:

( 5) H. F. Jepsen:

( 6) A. K. Higgins \& N. J. Soper:

( 7) J. D. Friderichsen \& H. J. Bengaard:

( 8) A. Steenfelt \& U. H. Jakobsen:

( 9) M. Kelly \& O. Bennike:

(10) N. Henriksen \& H. F. Jepsen:

(11) F. Rolle \&

(12) F. Getreuer Christiansen:
Cambro-Ordovician platform; lithostratigraphy, palaeontology and sedimentology. Freuchen Land - Warming Land.

Lower and Middle Ordovician platform; stratigraphy and sedimentology. Freuchen Land - Washington Land.

Cambro-Ordovician platform; stratigraphy and sedimentology. Freuchen Land - Washington Land.

Silurian turbidite sequence; stratigraphy and sedimentology. Nyeboe Land - Wulff Land.

Late Proterozoic to Silurian stratigraphy and structural geology of Wulff Land: a detailed cross-section from the unfolded platform to the folded trough.

Cambro-Ordovician slope and trough; stratigraphy and structural geology. Nansen Land - Nyeboe Land.

Deformed Cambrian trough sequence in
Lithostratigraphy and structural geology.

Reconnaissance geochemical exploration. Nansen Land Warming Land.

Reconnaissance Quaternary geology. Nansen Land - Hall Land.

Precambrian crystalline basement of southern Wulff Land.

Source rock investigations in the Cambro-Silurian platform and trough sequence. Freuchen Land - Washington Land.

Three major tectono-stratigraphic units occur in this part of North Greenland. The oldest unit is the Precambrian crystalline basement which forms the northernmost exposed part of the Greenland shield; this outcrops in a small area around the head of Victoria Fjord at the rim of the Inland Ice. The second major unit is a sequence of stable platform sediments, up to $3-4 \mathrm{~km}$ in thickness, which overlies the crystalline rocks. The platform sequence comprises shallow water epicontinental deposits dominated by carbonate deposits and spanning a time segment from Early Cambrian to late Silurian (fig. 4); it is exposed in a broad eastwest belt in the southern part of the region. The third major unit is an up to $8-10 \mathrm{~km}$ thick deep-water sequence of mainly clastic sediments deposited on the slope and trough to the north of the platform. These deposits largely comprise Cambrian to Silurian turbiditic sediments, dominated by shales and sandstones, but with important intercalations of carbonates. Northwards this deep-water sequence is increasingly involved in Upper Palaeozoic (Ellesmerian) deformation which gave rise to the North Greenland fold belt. These tectonostratigraphic units can be traced as $\mathrm{E}-\mathrm{W}$ trending belts along the northern border of the 


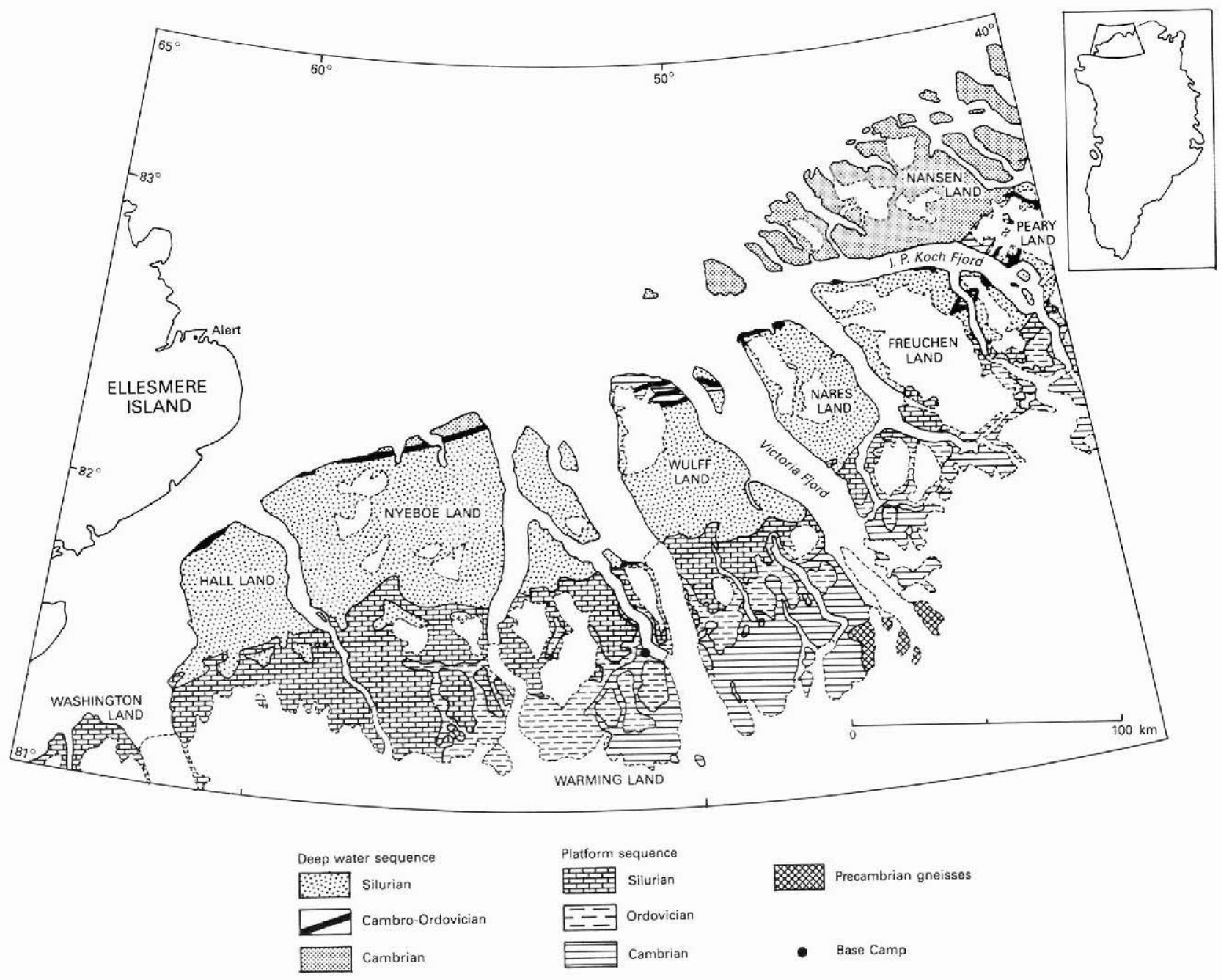

Fig. 4. Geological sketch map of central and western North Greenland showing results of mapping in 1984 and of photo-interpretation. 
Greenland shield. The eastern segments of the belts occur in the Peary Land region, and the western continuation extends into Ellesmere Island and the Canadian archipelago. Many aspects of the geology of North Greenland and Ellesmere Island have recently been summarised in the symposium volume concerning the possibilities of wrench displacements along Nares Strait, the channel separating North Greenland and Ellesmere Island (Dawes \& Kerr, 1982).

Investigations of the exposed areas of the Greenland shield were carried out by N. Henriksen and H. F. Jepsen who mainly mapped the extent of this Precambrian crystalline area and collected samples for $\mathrm{Rb} / \mathrm{Sr}$ whole rock and zircon age dating studies. The crystalline rocks outcrop at the head of Victoria Fjord over an area about $20 \times 30 \mathrm{~km}$ in size, and are exposed on three nunataks and two areas in southern Wulff Land at the rim of the Inland Ice. Sediments of the late Proterozoic (?) Morænes $\emptyset$ Formation and the Lower Cambrian Portfjeld Formation (Jepsen, 1971; O'Connor, 1979) unconformably overlie the crystalline rocks, and indicate a Precambrian age for the basement. The exposed rocks are dominated by homogeneous, foliated, leucocratic biotite gneisses which locally grade into almost granitic rocks. The gneisses include everywhere black amphibolite bands (sheets) and occasional bands of supracrustal rocks. All units are migmatised to some extent, and are affected by at least two phases of folding.

The Lower Palaeozoic carbonate platform sequence was mapped and studied by three two-man teams, co-ordinated by J. S. Peel. The general regional aspects were mainly studied by J. S. Peel (GGU) and S. C. Wright (Oxford University) who mapped the Cambro-Ordovician rocks between Freuchen Land and Warming Land. The Lower Cambrian clastic Buen Formation (Jepsen, 1971; Peel, 1982) could be traced westwards from Peary Land to Warming Land, whereas the Lower Cambrian to earliest Ordovician Brønlund Fjord Group and Tavsens Iskappe Group (Ineson \& Peel, 1980) grade westwards into a shallow water, marine, carbonate platform succession, which will be given new stratigraphical names. The Ordovician carbonate sequence was studied by M. Sønderholm assisted by P. H. Due (both Copenhagen University) and by M. P. Smith and I. D. Bryant (both Nottingham University). M. Sønderholm and P. H. Due recognised two Lower to Middle Ordovician shallowing-upwards sequences in Washington Land. Both begin with shallow subtidal carbonates and end with intertidal deposits with evaporites. The two shallowing upwards cycles are also recognised further east between Warming Land and Nares Land. However, the sequence thins eastwards and changes facies making a new stratigraphical nomenclature necessary in part. In addition to studying the Morris Bugt Group (Peel \& Hurst, 1980; Hurst, 1980) and the 'White marker sandstone' (Peel, 1980), M. P. Smith and I. D. Bryant collected conodont samples from the whole Ordovician platform sequence, with particularly close sampling around the 'White marker sandstone'. This latter unit can be traced as a westerly thinning bed into the uppermost part of the Middle Cambrian to Early Lower Ordovician Cass Fjord Formation in Washington Land (Henriksen \& Peel 1976). The Morris Bugt Group with its four formations was recognised from Washington Land to Freuchen Land. To the east, most of the group is equivalent to the Børglum River Formation (Christie \& Peel, 1977; Peel, 1982). J. S. Peel and S. C. Wright also visited Hans $\varnothing$, a small island lying in Kennedy Kanal between Greenland and Cananda, noting a Silurian carbonate sequence comparable to that described from adjacent Washington Land by Hurst (1980).

The Silurian turbidite sequence was studied by J. C. Escher and P.-H. Larsen (both GGU) who mapped the region between northern Nyeboe Land and northern Wulff Land, with the 
adjacent islands. In general the stratigraphical scheme described by Hurst \& Surlyk (1982) was followed, but two new conspicuous units were distinguished in the lower part of the Silurian flysch. The flysch sequence thickens rapidly to the north where in the northern part of Nyeboe Land it reaches a thickness provisionally estimated at $6 \mathrm{~km}$. The lowest thick sandstone turbidite unit (Merqujôq Formation) conformably overlies Ordovician cherts; it is overlain by a second thick sandstone turbidite unit (Lauge Koch Land Formation) which interdigitates with two distinctive chert pebble conglomerate horizons. To the south, along the margin between platform and trough, carbonate build-ups protrude through the flysch sequence. Here the Lauge Koch Land Formation onlaps the Silurian carbonate platform sequence, and is separated from them by a few hundred metres of platform/slope sediments dark shales and carbonates with conspicuous carbonate conglomerates and blocks. Westwards the Lauge Koch Land Formation interdigitates and is overlain by the youngest mapped unit of silty mudstones (Chester Bjerg Formation). From the south to the north the flysch sequence is characterised by a progressive increase of deformation with E-W trending structures. Five successive zones of different tectonic styles have been recognised. Near the platform to the south the sequence is undeformed but farthest to the north prominent eastwest trending folds are conspicuous.

Stratigraphical and structural investigations in the North Greenland fold belt were carried out by two teams. A. K. Higgins (GGU) and N. J. Soper (Sheffield University) worked mainly in the deformed Cambro-Ordovician slope and trough sequence between western Peary Land and northern Nyeboe Land, while J. D. Friderichsen (GGU) and H. J. Bengaard (Copenhagen University) worked in the more severely folded Cambrian trough sequence in the eastern part of Nansen Land. The outcrops of Cambrian Paradisfjeld Group and Polkorridoren Group in Nansen Land represent the westward continuation of those described from the Peary Land region (Higgins et al., 1981). In Nansen Land, the Paradisfjeld Group is a thick succession of impure limestones, with a limestone olistolith horizon and a light coloured upper sequence with associated conglomerates forming a good marker unit. The overlying turbiditic Polkorridoren Group outcrops south and north of a major anticlinorium of Paradisfjeld Group rocks. South of the anticlinorium the sequence comprises mainly siltstones with important levels of limestone olistoliths with dimensions up to several hundred metres across. North of the anticlinorium the turbiditic sequence is thicker and generally more psammitic. From north to south a transition may be demonstrated between the Lower Cambrian Polkorridoren Group of Nansen Land and the clastic Buen Formation which covers the slope and platform areas to the south. Along strike facies changes can also be recognised between the Cambro-Ordovician clastic rocks and cherts of the Vølvedal Group and Amundsen Land Group in the east (Friderichsen et al., 1982) and carbonates and cherts in the west.

To a large extent the pattern of deformation already known from reconnaissance work and photogeological studies was confirmed. The platform strata in the south are essentially undeformed. Northwards deformation increases through zones of weak folding to a zone of southerly overturned folds and north-dipping thrusts with southwards displacement. In eastern Nansen Land, north of the zone with south-verging structures, J. D. Friderichsen and H. $\mathrm{J}$. Bengaard recognised three E-W trending phases of Ellesmerian deformation. Folds from the first deformation have steep north-dipping axial planes in the south but become overturned to the north in northern Nansen Land. Late minor local folds with generally N-S trends are considered to be post-Ellesmerian. 
H. F. Jepsen has mapped parts of Wulff Land in connection with a more detailed survey aimed at compiling maps at a scale of 1:100 000 accompanied by constructed profiles. This work is based on combined field investigations and detailed photogrammetric mapping using a computer aided Kern PG-2 stereoplotter instrument with a semi-automatic drawing table (Dueholm, 1979). In southern Wulff Land specific investigations were made of the lowermost part of the sedimentary sequence overlying the crystalline basement. Jepsen located exposures of the Morænes $\emptyset$ Formation with tillites, and equivalents of the Portfjeld Formation (Jepsen, 1971) with a spectacular olistostrome comprising blocks of dolomite, quartzite and basement gneisses up to several tens of metres in size. H. F. Jepsen has also recognised to major sets of east-west trending normal faults with up to several hundred metres vertical displacement. In mapping the Silurian platform carbonates of the Washington Land Group (Hurst, 1980) in central Wulff Land, H. F. Jepsen placed particular emphasis on identification of ' photogenic' horizons or units, which can be recognised on black and white aerial photographs and thus mapped with precision using photogrammetric methods.

A reconnaissance geochemical exploration programme was carried out by A. Steenfelt (GGU) assisted by U. H. Jakobsen (Copenhagen University). Earlier sampling of drainage sediments was carried out in the Peary Land region in 1979-1980 (Henriksen, 1980, 1981). In 1984 about 500 stream-sediment samples were collected at a density of one sample per 30 $\mathrm{km}^{2}$ in the region from Nansen Land in the north-east to Warming Land in the south-west. The aim of this survey is to outline large geochemical provinces and give indications of possible mineralised districts. At selected localities representing different types of geological setting detailed sampling of stream sediments, heavy mineral concentrates, soil and various plants was carried out. As in the previous investigations from the Peary Land region (Ghisler \& Stendal, 1980; Steenfelt, 1980) the stream sediment samples will be analysed, the heavy mineral concentrates studied under the microscope, and the soil and plants analysed for selected elements. Mineralisations were located in several areas. The most significant was the occurrence of $\mathrm{Zn}, \mathrm{Cu}$ and possibly $\mathrm{Pb}$ sulphides in a 5-7 m wide calcite vein in northern Freuchen Land; the calcite vein occurs in an E-W trending fault zone on the south side of a prominent anticline and can be traced for more than $1 \mathrm{~km}$.

A reconnaissance of the Quaternary geology was undertaken by M. Kelly (Lancaster University) and $O$. Bennike (Copenhagen University) in order to establish a general stratigraphic scheme, and to obtain ground control data for photogeological interpretation. A regional relative chronology of six glacial events has been established. The events reflect, with decreasing age, ice sheet margin features from beyond the present coast to a stage where the margin was close to or behind the present margin of the Inland Ice. A major readvance probably reached its maximum in historic time. Deposits of marine sediments reflect marine limits between $120 \mathrm{~m}$ and $50 \mathrm{~m}$ above sea level and can be related to the later glacial stages. Several distinct marine faunas are present in the sediments and a large number of samples were collected for a $\mathrm{C}^{14}$ age determination programme.

The source rock project carried out by F. Rolle and F. Getreuer Christiansen (both GGU) was aimed at a systematic sampling of possible petroleum source rocks, and continues the previous investigations in the Peary Land region (Rolle, 1981); this work is described elsewhere in this report. The investigations revealed that potential source rocks occur in a Lower-Middle Cambrian carbonate and shale formation in the platform succession and in a black shale and lime mudstone succession along the Silurian trough margin.

Oblique aerial photography, in both black and white and colour, was undertaken along 
many coast and valley sections by $\mathrm{N}$. Henriksen and J. Lautrup using the chartered Twin Otter aircraft. The main part of the region to the east of Nyeboe Land has been systematically covered. Routes were selected to give as much geological information as possible along the well exposed sections. The black and white photographs were taken with approximately 20 per cent overlap and give as far as possible total coverage. Colour photographs were taken at intervals, as an aid to identifying features on the black and white films. In all c. 1400 black and white photographs in $4.5 \times 6.0 \mathrm{~cm}$ format and c. 700 colour photographs in $24 \times 36 \mathrm{~mm}$ format have been taken.

\section{Future work}

The 1984 systematic field work in the central and western parts of North Greenland was completed according to plan, and more or less detailed maps of more than half of the region have been prepared. Some activities have been completed, e.g. the Quaternary investigation, but most activities will continue in the 1985 season. New activities in 1985 will include investigations in the Silurian platform carbonates, and geomagnetic and palaeomagnetic investigations. The source rock project will be expanded to include a shallow drilling programme to obtain unweathered samples.

Acknowledgements. The 1984 field work was carried out with the help of many external institutions and their personnel. The Royal Dansh Air Force supplied C-130 transport co-ordinated by Major J. F. Clemmensen. Department of National Defence Headquarters, Ottawa, gave permission to use CFS Alert as supporting base in connection with mobilisation and demobilisation; this work was coordinated by Major E. P. Luhtala, Ottawa, and Major R. L. Stevens, Commanding Officer CFS Alert. Polar Continental Shelf Project, Ottawa, supported with hut facilities at Alert and the Danish Liaison Officer at Thule Air Base, Commander $\mathbf{H}$. Bruun de Neergaard, helped with co-ordination and communication through Thule Air Base. The Meteorological Institute in Copenhagen gave weather forecasts for the expedition area throughout the season. A. K. Higgins and other colleagues at GGU gave valuable suggestions and comments on the manuscript.

\section{References}

Christie, R. L. \& Peel, J. S. 1977: Cambrian-Silurian stratigraphy of Børglum Elv, Peary Land, eastern North Greenland. Rapp. Gronlands geol. Unders. 82, $48 \mathrm{pp}$.

Dawes, P. R. 1984: Progamme NordGrøn (PNG) 1983-1985: regional mapping and geological studies in western and central North Greenland. Rapp. Gronlands geol. Unders. 120, 18-24.

Dawes, P. R. \& Kerr, J. W. (edit.) 1982: Nares Strait and the drift of Greenland: a conflict in plate tectonics. Meddr Grønland, Geosci. 8, 396 pp.

Dueholm, K. S. 1979: Geological and topographic mapping from aerial photographs. Meddr Inst. Surv. Photogrammetry, Danm. Tekn. Højsk. 10, 204 pp.

Friderichsen, J. D., Higgins, A. K., Hurst, J. M., Pedersen, S.A.S., Soper, N. J. \& Surlyk, F. 1982: Lithostratigraphic framework of the Upper Proterozoic and Lower Palaeozoic deep water clastic deposits of North Greenland. Rapp. Gronlands geol. Unders. 107, $19 \mathrm{pp}$.

Ghisler, M. \& Stendal, H. 1980: Geochemical and ore microscopic investigations on drainage sands from the Peary Land region, North Greenland. Rapp. Grønlands geol. Unders. 99, 121-128.

Henriksen, N. 1980: Collection of stream sediments for a reconnaissance geochemical survey from the Peary Land region, North Greenland. Rapp. Grønlands geol. Unders. 99, 119-120. 
Henriksen, N. 1981: Collection of samples for a reconnaissance geochemical survey from the Peary Land - Kronprins Christian Land region, North Greenland. Rapp. Grønlands geol. Unders. 106, 8587.

Henriksen, N. \& Peel, J. S. 1976: Cambrian - Early Ordovician stratigraphy in south-western Washington Land, western North Greenland. Rapp. Grønlands geol. Unders. 80, 17-23.

Higgins, A. K., Friderichsen, J. D. \& Soper, N. J. 1981: The North Greenland fold belt between central Johannes V. Jensen Land and eastern Nansen Land. Rapp. Grønlands geol. Unders. 106, 35-45.

Hurst, J. M. 1980: Silurian stratigraphy and facies distribution in Washington Land and western Hall Land, North Greenland. Bull. Grønlands geol. Unders. 138, 95 pp.

Hurst, J. M. \& Surlyk, F. 1982: Stratigraphy of the Silurian turbidite sequence of North Greenland. Bull. Grønlands geol. Unders. 145, 121 pp.

Ineson, J. R. \& Peel, J. S. 1980: Cambrian stratigraphy in Peary Land, eastern North Greenland. Rapp. Grønlands geol. Unders. 99, 33-42.

Jepsen, H. F. 1971: The Precambrian, Eocambrian and Early Palaeozoic stratigraphy of the Jørgen Brønlund Fjord area, Peary Land, North Greenland. Bull. Grønlands geol. Unders. 96, 42 pp.

O'Connor, B. 1979: The Portfjeld Formation (? Early Cambrian) of eastern North Greenland. Rapp. Grønlands geol. Unders. 88, 23-28.

Peel, J. S. 1980: Cambrian and Ordovician geology of Warming Land and southern Wulff Land, central North Greenland. Rapp. Grønlands geol. Unders. 101, 55-60.

Peel, J. S. 1982: The Lower Paleozoic of Greenland. In Embry, A. F. \& Balkwill, H. R. (edit.) Arctic Geology and Geophysics. Mem. Can. Soc. Petrol Geol. 8, 309-330.

Peel, J. S. \& Hurst, J. M. 1980: Late Ordovician and early Silurian stratigraphy of Washington Land, western North Greenland. Rapp. Grønlands geol. Unders. 100, 18-24.

Rolle, F. 1981: Hydrocarbon source rock sampling in Peary Land 1980. Rapp. Grønlands geol. Unders. 106, 99-103.

Steenfelt, A. 1980: The geochemistry of stream silt, North Greenland. Rapp. Grønlands geol. Unders. 99, 129-135.

\title{
Project 'Nordolie': hydrocarbon source rock investigations in central North Greenland
}

\author{
F. G. Christiansen and F. Rolle
}

The project 'Nordolie' was initiated under the Danish Ministry of Energy's Research Programme 1983. The aim of the project is to obtain general knowledge about the source rock geology of central North Greenland. Similar investigations have previously been carried out in eastern North Greenland (Rolle, 1981; Rolle \& Wrang, 1981).

The main purpose of the project is to study the presence and distribution of potential hydrocarbon source rocks in the region and to evaluate the thermal maturity pattern. Studies of reservoir properties, trapping possibilities, and other aspects of petroleum geology will accordingly have a much lower priority.

Field work was carried out by two geological field teams from June to August 1984 and 